\title{
Islamic banking, credit, and economic growth: Some empirical evidence
}

\author{
Guglielmo Maria Caporale ${ }^{1,2,3}$ (D) | Mohamad Husam Helmi ${ }^{4}$
}

\author{
${ }^{1}$ Department of Economics and Finance, \\ Brunel University London, London, UK \\ ${ }^{2}$ CESifo, Munich, Germany \\ ${ }^{3}$ DIW, Berlin, Germany \\ ${ }^{4}$ Department of Economics and Finance, \\ Durham University Business School, \\ Durham, UK

\section{Correspondence \\ Guglielmo Maria Caporale, Department of Economics and Finance, Brunel \\ University London, London UB8 3PH, \\ UK. \\ Email: guglielmo-maria.caporale@brunel. ac.uk}

JEL Classification: C32; C33; G21; O11

\begin{abstract}
This paper examines the effects of Islamic banking on the causal linkages between credit and gross domestic product (GDP) by comparing two sets of seven emerging countries, the first without Islamic banks and the second with a dual banking system including both Islamic and conventional banks. Unlike previous studies, it checks the robustness of the results by applying both time series and panel methods; moreover, it tests for both long- and short-run causality. In brief, the findings highlight significant differences between the two sets of countries reflecting the distinctive features of Islamic banks. Specifically, the time series analysis provides evidence of long-run causality running from credit to GDP in countries with Islamic banks. This is confirmed by the panel causality tests, although in this case short-run causality in countries without Islamic banks is also found.
\end{abstract}

\section{KEYWORDS}

causality tests, credit, growth, Islamic banking

\section{1 | INTRODUCTION}

The finance-growth nexus has been extensively investigated in the literature, with mixed evidence: Some studies reach the conclusion that financial development boosts economic growth (e.g., Beck, Degryse, \& Kneer, 2014; King \& Levine, 1993; McKinnon, 1973; Schumpeter, 1911; Shaw, 1973), whereas others argue that causality runs in the opposite direction (e.g., Ang \& McKibbin, 2007; Berthelemy \& Varoudakis, 1996; Robinson, 1953); Rousseau and Wachtel (2011) have reported that the linkage has become weaker over time. Moreover, there is no consensus on how to measure financial development and how to handle the endogeneity problem. Most recently, the Bank for International Settlements (BIS) has focused on the role of credit and whether it might be used as an early warning indicator, because excessive lending is thought to be one of the main factors that have caused the global financial crisis of 2007-2008. The credit-to-gross domestic product (GDP) ratio was in fact adopted by the Basel III committee (2010) as a guide to build up countercyclical capital buffers during booms in order to use them during crises (see Drehmann, 2013).

An interesting issue not thoroughly analysed in the literature is whether the relationship between credit and economic growth is different in countries with Islamic banks. Such institutions are not allowed to charge a predetermined interest rate, which is replaced by the ex post profit and loss sharing (PLS) rate (Chong \& Liu, 2009). Further, they can only provide credit for transactions related to a tangible, underlying asset and cannot engage in any speculative activities (Hasan \& 
Dridi, 2010; Kammer et al., 2015; Khan, 2010). Only a few empirical studies of countries with Islamic banking exist. Majid and Kassim (2010) find evidence supporting the "supply-leading" view. By contrast, Furqani and Mulyany (2009) report that economic growth causes financial development only in the short run in a country with Islamic banking such as Malaysia-on the whole, their analysis is consistent with the "demand-following" view. Abduh and Omar (2012) find bidirectional causality between Islamic finance and economic growth in Indonesia. Most recently, Imam and Kpodar (2016) conclude that countries with Islamic banks experience faster economic growth than those without Islamic banks.

The present paper aims to examine in depth the effects of Islamic banking on the causal linkages between credit and GDP by comparing two sets of seven emerging countries, the first without Islamic banks and the second with a dual banking system including both Islamic and conventional banks. Unlike previous studies, it checks the robustness of the results by applying both time series and panel methods. Moreover, it tests for both long- and short-run causality; the former has been analysed in the traditional literature on the finance-growth nexus, whereas the latter is relevant for the current debate on macroprudential policies and the attempt by the BIS to identify the best early warning indicators. Our analysis also seeks to contribute to the ongoing debate on whether the PLS paradigm of Islamic banking might lead to an optimal distribution of funds (Siddiqi, 1999) and on the role of Islamic finance in promoting economic growth rather than causing an increase in the price level by linking all financial transaction to real economic activities (Chapra, 1992; Gulzar \& Masih, 2015; Kammer et al., 2015; Mills \& Presley, 1999).

In brief, our findings highlight significant differences between the two sets of countries. Specifically, the time series analysis provides evidence of long-run causality running from credit to GDP in countries with Islamic banks. This is confirmed by the panel causality tests, although in this case short-run causality in countries without Islamic banks is also found. The layout of the paper is as follows: Section 2 briefly reviews the principles of Islamic banking; Section 3 describes the data; Section 4 outlines the methodology; Section 5 discusses the empirical results; and finally, Section 6 offers some concluding remarks.

\section{2 | ISLAMIC BANKING}

The principles of Islamic finance are based on the Quran, hadith, ${ }^{1}$ and Islamic jurisprudence (Sharia). The first is the prohibition of interest payment (Riba), defined by some Islamic scholars as usury and by others as any predetermined interest rate (Chong \& Liu, 2009). In the
Holy Quran, 10 statements/verses condemned the practice of Riba or charging predetermined interest rate. For example, the Surah/chapter al-Baqarah says: "O you who believe! Fear God and give up whatever remains of Riba (usury), if you are believers" (Quran 2:278). Another verse in the Surah al-Baqarah distinguishes between Riba and trading: "Allah has allowed trading and forbidden Riba (usury)" (Quran 2:275). Further, Ebrahim, Molyneux, and Ongena (2017) defined usury as an injunction to protect property rights. Therefore, many financial contracts are constructed on the basis of the difference between trading and Riba as well as Islamic jurisprudence (Sharia), for instance, Musharaka (partnership), Mudharabah (profit sharing), Murabahah (cost plus), and Ijarah (leasing) contracts. ${ }^{2}$ Thus, Islamic financial institutions are not allowed to make money through pure financing, and financial contracts must be linked directly to real economic activities (Gulzar \& Masih, 2015; Kammer et al., 2015). Each financial transaction is underpinned by an existing or potential real asset, in contrast to the case of conventional banks that can provide credit without such constraints (see Askari, 2012; Siddiqi, 2006).

The second principle is based on the PLS paradigm between the two parties of any financial contract, which is seen as a crucial feature that distinguishes Islamic from conventional banks. Furthermore, the conventional ex ante interest rate, which is a risk-shifting rate, is replaced by the ex post PLS rate, which is instead a risk-sharing rate (Chong \& Liu, 2009). This is thought to encourage Islamic banks to invest in small and medium enterprises and long-term ventures and thus to stimulate economic growth (Chapra, 1992; Mills \& Presley, 1999). Solarin, Hammoudeh, and Shahbaz (2018) argue that banks and borrowers are involved in venture financing even though Islamic financial transactions are expected to be based on PLS. The prohibition of the conventional ex ante interest rate is viewed as a foundation for improvements in both social justice and economic efficiency (Berg \& Kim, 2014; El-Gamal, 2006).

The third principle does not allow Islamic banks to engage in any speculative transactions, option and futures contracts, hedging, toxic assets, gambling, and funding of any activities, which are considered harmful to the community such as producing alcohol (Hasan \& Dridi, 2010; Kammer et al., 2015; Khan, 2010). It is thought that financing such activities would cause an increase in prices rather than contributing to GDP. The fourth principle requires asset backing: Transactions should be related to a tangible, underlying asset. In addition, the main criterion for the allocation of credit by Islamic banks is the productivity of the project, instead of the creditworthiness of the customer as in the case of conventional banks. Therefore, credit is channelled to productive investment rather than 
speculative activities, which are not allowed according to the principles of Islamic finance (Di Mauro et al., 2013). Bernanke (2009) and Turner (2009) argue that excessive and unproductive credit growth, investment in speculative transactions, and interest-based debt financing were in fact some of the main causes of the 2007-2008 financial crisis. In contrast, in the Islamic banking system, these activities are either not allowed or partly mitigated-for instance, as highlighted by Mohieldin (2012), asset-backed debt guarantees a direct relationship between loans and the real economy. In this way, greater market discipline and financial stability are achieved (Di Mauro et al., 2013). Given the distinctive features of Islamic banking, one would expect to find differences in the role of credit between countries with and without Islamic banks. This is the issue analysed in this study.

\section{3 | DATA DESCRIPTION}

We investigate the causal relationship between real credit to the private sector and real GDP in 14 emerging countries with sufficiently long time series. These are divided into two groups (see Table 1): The first includes countries without Islamic banks, specifically Latin American countries with a similar level of development to those with Islamic banks and without recent long periods of colonial history affecting their institutions (viz., Argentina, Brazil, Chile, Costa Rica, Ecuador, Guatemala, and Peru); the second includes countries with both Islamic and conventional banks according to the Bankscope database (Malaysia, Indonesia, Turkey, Iran, Jordan, Singapore, and Tunisia). Oil-exporting countries with Islamic banks are excluded from the sample because their economic growth might be mainly driven by oil revenues rather than financial development or credit. However, Iran has been included because its economy has many other industrial sectors and does not depend solely on oil revenues.
The data source is the International Monetary Fund database. The (seasonally adjusted) series are credit to the private sector (Cr), GDP, and the consumer prices index (CPI). These have been logged, and real credit (RCR) and GDP (RGDP) series have been created using the price deflator. The model we estimate to analyse the causal linkages between real credit and real GDP also includes the following variables: the real exchange rate $\left(R E X_{t}\right)$, the inflation rate $\left(I N F_{t}\right)$, and the real interest rate $\left(I_{t}\right)$. The real exchange rate $\left(E X_{t}\right)$ is added as an international variable that might potentially influence GDP. The real interest rate affects consumption and investment decision, which have an impact on demand for credit from banks as well as economic growth (Kassim, 2016). The inflation rate is a measure of price stability that can have effects on both the financial sector and the real economy. The choice of these additional variables is in line with existing empirical studies such as Gheeraert (2014), Kassim (2016), Abedifar, Hasan, and Tarazi (2016), and Imam and Kpodar (2016).

Following the International Monetary Fund definition of credit, ${ }^{3}$ we calculated credit as gross credit injected into all private sectors of the economy, that is, excluding credit to the government. This is because credit to the private sector increases in boom periods and decreases during credit crunches or crises, whereas credit to the public sector moves in the opposite direction (see Drehmann, Borio, \& Tsatsaronis, 2011).

The credit to GDP ratio in countries without Islamic banks was around $20-30 \%$ in 2001 in most of these countries. It then increased reaching around $60 \%$ in Brazil and Costa Rica in 2016. However, it is much higher in Chile, where it increased from $64.48 \%$ in 2001 to $80.76 \%$ in 2016 (see Figure 1). On the other hand, most countries with Islamic banks have a higher credit to GDP ratio, which was above 60\% in 2001 except for Indonesia and Turkey, where it reached $66.20 \%$ in 2016 (see Figure 2). Singapore and Malaysia experienced a decrease in this ratio between 2001 and 2007-2008, and then it increased to around

TABLE 1 Sample of countries

\begin{tabular}{|c|c|c|c|}
\hline $\begin{array}{l}\text { Data set 1: Seven countries } \\
\text { without Islamic } \\
\text { banks }\end{array}$ & Period & $\begin{array}{l}\text { Data set 2: Seven countries } \\
\text { with Islamic } \\
\text { banks }\end{array}$ & Period \\
\hline Brazil & 2001Q4-2016Q4 & Turkey & 2001Q4-2016Q4 \\
\hline Chile & 1997Q4-2016Q4 & Iran & 1994Q1-2007Q4 ${ }^{\mathrm{a}}$ \\
\hline Ecuador & 2001Q4-2016Q4 & Jordan & 1992Q1-2016Q4 \\
\hline Guatemala & 2001Q4-2016Q4 & Tunisia & 2000Q1-2015Q3 \\
\hline Peru & 1996Q1-2016Q4 & Malaysia & 2001Q4-2016Q4 \\
\hline
\end{tabular}

${ }^{\mathrm{a}}$ Data are not available for Iran beyond 2007. 
FIGURE 1 Credit to gross domestic product ratio in countries without Islamic banks [Colour figure can be viewed at wileyonlinelibrary.com]
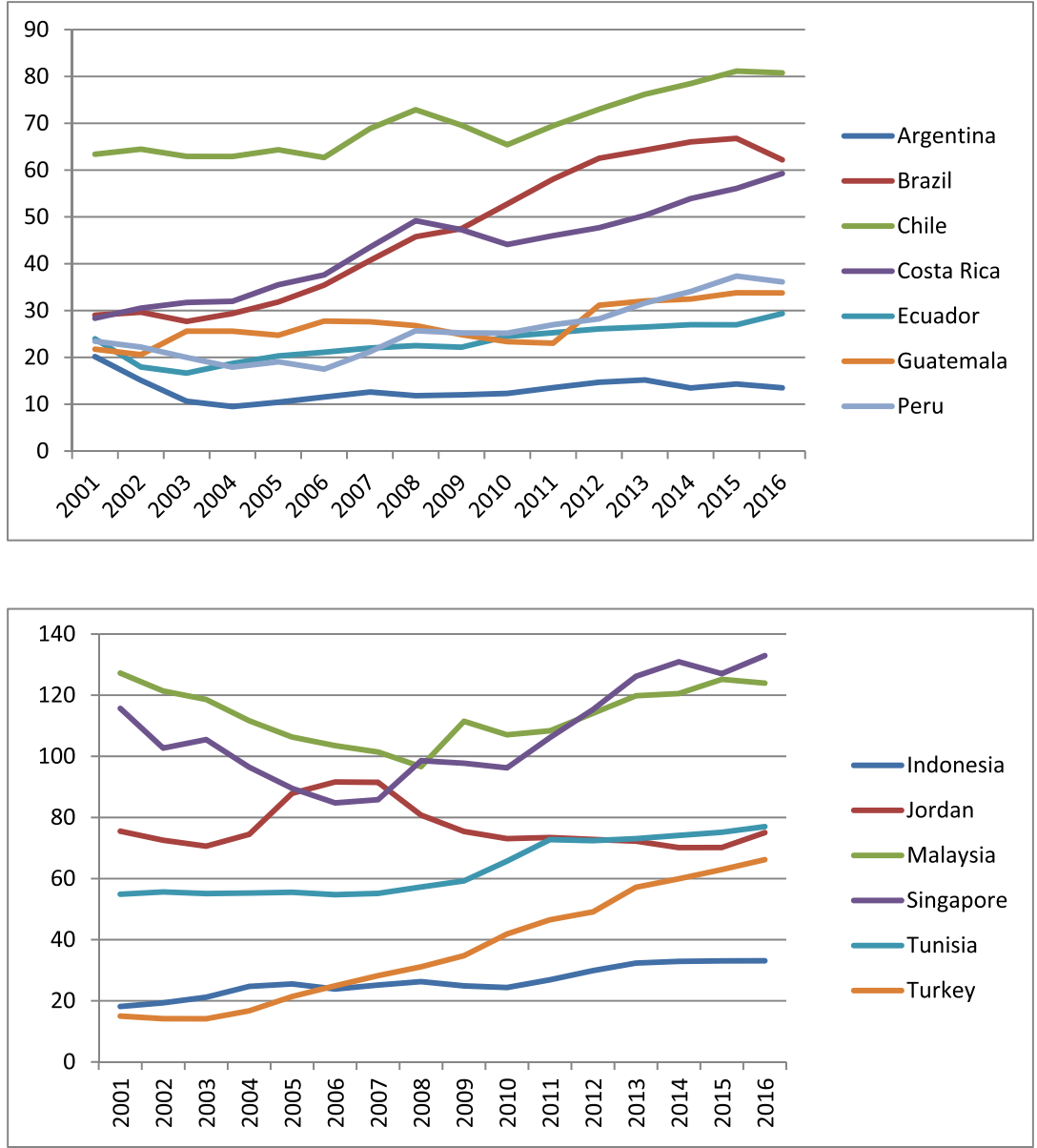

FIGURE 2 Credit to gross domestic product ratio in countries with Islamic banks [Colour figure can be viewed at wileyonlinelibrary.com]

$$
\begin{aligned}
\Delta R C R_{t}=\alpha_{2} & +\sum_{i=1}^{k} \varphi_{2 i} \Delta R C R_{t-i}+\sum_{i=1}^{k} \beta_{2 i} \Delta R G D P_{t-i} \\
& +\sum_{i=1}^{k} \partial_{2 i} \Delta E X_{t-i}+\sum_{i=1}^{k} \gamma_{2 i} \Delta I N F_{t-i} \\
& +\sum_{i=1}^{k} \delta_{2 i} \Delta I_{t-i}+\epsilon_{2 t},
\end{aligned}
$$

where $R G D P_{t}$ is the log of real GDP whereas $R C R_{t}$ stands for the log of real credit to the private sector, $E X_{t}$ is the real exchange rate, $I N F_{t}$ is the inflation rate, $I_{t}$ is the real interest rate, $\Delta$ is the first difference operator, $\alpha_{1}$ and $\alpha_{2}$ are constant drifts, $\beta_{j i}, \varphi_{j i}, \partial_{j i}, \gamma_{j i}$, and $\delta_{j i}$ are polynomials of order $k-1$, and $\epsilon_{1 t}$ and $\epsilon_{2 t}$ are the residuals. Failure to reject the null hypothesis of $H_{0}: \sum_{i=1}^{k} \varphi_{1 i}=0$ implies that real credit to the private sector does not Granger-cause real GDP. Similarly, failure to reject the null hypothesis of $H_{0}: \sum_{i=1}^{k} \beta_{2 i}=0$ implies that real GDP does not Granger-cause real credit to the private sector.

Following Engle and Granger (1987), if the order of integration of the series is $I(1)$ and they are cointegrated, an error correction term (ECT) is introduced into the model. Therefore, a VECM is specified as follows: 


$$
\begin{aligned}
\Delta R G D P_{t}=\alpha_{1} & +\sum_{i=1}^{k} \beta_{1 i} \Delta R G D P_{t-i}+\sum_{i=1}^{k} \varphi_{1 i} \Delta R C R_{t-i} \\
& +\sum_{i=1}^{k} \partial_{1 i} \Delta E X_{t-i}+\sum_{i=1}^{k} \gamma_{1 i} \Delta I N F_{\mathrm{t}-i}+\sum_{i=1}^{k} \delta_{1 i} \Delta I_{t-i} \\
& +\theta_{1} E C T_{t-1}+\epsilon_{1 t},
\end{aligned}
$$

$$
\begin{aligned}
\Delta R C R_{t}=\alpha_{2} & +\sum_{i=1}^{k} \varphi_{2 i} \Delta R C R_{t-i}+\sum_{i=1}^{k} \beta_{2 i} \Delta R G D P_{t-i} \\
& +\sum_{i=1}^{k} \partial_{2 i} \Delta E X_{t-i}+\sum_{i=1}^{k} \gamma_{2 i} \Delta I N F_{t-i}+\sum_{i=1}^{k} \delta_{2 i} \Delta I_{t-i} \\
& +\theta_{2} E C T_{t-1}+\epsilon_{2 t},
\end{aligned}
$$

where $\alpha_{1}$ and $\alpha_{2}$ are constant drifts, $E C T_{t-1}$ is the error correction term, which represents the deviations from the long-run cointegration relationship, and $\theta_{1}$ and $\theta_{2}$ denote the speeds of adjustment towards the long-run equilibrium, which are expected to be negative.

Therefore, there are two sources of causality between the two variables of interest $R G D P_{t}$ and $R C R_{t}$, either through the error correction term $\left(E C T_{t-1}\right)$ or through the lagged dynamic terms $\triangle R C R_{t-i}$ in Equation (3) or $\triangle R G D P_{t-i}$ in Equation (4). Consequently, one can test for three types of causality between real GDP and real credit to the private sector. First, one can test whether $\Delta R C R_{t}$ Granger-causes $\Delta R G D P_{t}$ in the short run by carrying out a Wald test of the null hypothesis $H_{0}: \sum_{i=1}^{k} \varphi_{1 i}=0$. Second, one can test for long-run causality by performing a weak exogeneity test on the coefficient of the lagged error correction term $E C T_{t-1}$. Failure to reject the null hypothesis $H_{0}: \theta_{1}=0$ implies that real credit to the private sector does not Granger-cause real GDP in the long run. Third, strong exogeneity can be tested by testing the joint significance of the coefficients on the lagged dynamic terms and the lagged error correction term (Engle, Hendry \& Richard, 1983; Charemza \& Deadman, 1992). The null hypothesis in this case is $H_{0}: \sum_{i=1}^{k} \varphi_{1 i}=\theta_{1}=0$. However, this test does not allow to distinguish between long- and short-run causality (Ang \& McKibbin, 2007). ${ }^{4}$

Time series techniques have been criticized because small sample distortions can affect the power of standard unit root and cointegration tests (see Christopoulos \& Tsionas, 2004). These issues can be addressed using panel approaches (Ang, 2008) to carry out cointegration tests with higher power (Persyn \& Westerlund, 2008). Hsiao, Mountain, and Ho-Illman (1995) argue that the panel approach yields more accurate inference. Further, this approach provided information on individual units and intertemporal dynamics, which might help in controlling the impact of unobserved or missing variables (Hsiao, 2007). The possible issue of collinearity between the current and lag variables (which is highly possible in time series) can be alleviated because of the interindividual differences (Griliches, 1967; Pakes \& Griliches, 1984). With this in mind, we also apply various panel methods to check the robustness of our findings (see below).

\section{5 | EMPIRICAL ANALYSIS}

\section{1 | Unit root tests}

As a first step, we carry out a battery of unit root tests to examine the stochastic properties of the individual series using augmented Dickey-Fuller (Dickey \& Fuller, 1981) and Phillips-Perron tests (Phillips \& Perron, 1988). These tests suggest that our variables are nonstationary $I(1)$ in the countries with and without Islamic banks. We also applied panel unit root tests, namely, the MW (Maddala \& Wu, 1999) and Im-Pesaran-Shin tests (Im, Pesaran, $\&$ Shin, 2003), ${ }^{5}$ which confirm that the variables can be characterized as $I(1){ }^{6}$

\section{2 | Cointegration tests}

Next, we test for the existence of a long-run relationship between real credit to the private sector and real GDP. For this purpose, we use both time series (Johansen, 1988, 1995) and panel cointegration (Westerlund, 2007) methods. $^{7}$ Because the multivariate tests of Johansen (1988, 1995) are very sensitive to the lag length (see Banerjee, Dolado, Galbraith, \& Hendry, 1993; Chang \& Caudill, 2005; Cheung \& Lai, 1993), we use the Schwarz information criterion to determine the optimal lag length but include extra lags when required to remove serial correlation (as in Hunter \& Menla Ali, 2014, where the Akaike information criterion is used instead). We run diagnostic tests for the residuals with the the BreuschGodfrey serial correlation LM test providing no evidence of any remaining serial correlation. Further, the null hypothesis of both homoscedasticity and normality cannot be rejected in any cases. Thus, we conclude that the vector autoregression models are data congruent and carry out the Johansen cointegration tests using the chosen optimal lag length. ${ }^{8}$ Furthermore, to achieve normality in the presence of some outliers in the data, the following dummies were included to remove the effect of extreme observations: Chile 2008Q1, Argentina 2002Q3, Guatemala 2005Q4, Tunisia 2011Q1, Jordan 2008Q1, and Singapore 2008Q4. These outliers mainly correspond to the recent $2007 / 2008$ financial crisis, the 
2001 dot-com bubble crisis in the United States, and the start of the Arab spring in Tunisia in January 2011. Juselius (2007) pointed out that ignoring the issue of outliers in the data would produce unreliable results. We follow Dimitraki and Menla Ali (2015) and control for outliers defined as such when the residual is greater than $|3.5 \sigma| .^{9}$

On the basis of the trace and eigenvalues statistics, the null of no cointegration is rejected at the $1 \%$ and $5 \%$ levels in the countries without Islamic banks (see Table 2, Panel A), as well as those with Islamic banks (see Table 2, Panel B); therefore, it appears that there is a stable long-run relationship between credit and GDP in every case. ${ }^{10}$

Next, we carry out panel cointegration tests, specifically an error correction-based panel cointegration test (Westerlund, 2007). Westerlund (2007) criticizes the panel residual-based tests (e.g., Kao, 1999; Pedroni, 2004), pointing out in particular that the common factor restriction might be invalid, and proposes four more advanced panel cointegration tests with higher power. The first two, $G_{\tau}$ and $G_{\alpha}$, are based on group-mean test statistics, which test the alternative hypothesis that the panel as a whole is cointegrated, whereas the other two, $p_{\tau}$ and $p_{\alpha}$, are pooled test statistics, which are designed to test the alternative that at least one of the individual cross-sectional units is cointegrated (Persyn \& Westerlund, 2008). The results for these tests are reported in Table 3. It can be seen that both group-mean statistics reject the null hypothesis of no cointegration in all three panels (comprising countries with and without Islamic banks and all countries in turn), suggesting the existence of a long-run relationship between real credit to the private sector and real GDP in each case. However, the other two panel statistics fail to reject the null hypothesis of no cointegration between the two variables.

\section{3 | Causality tests}

Next, we apply both time series and panel approaches to test for three types of causality (where the null hypothesis is that of no causality): short-run causality, using lags of the explanatory variables; long-run causality (weak exogeneity), using the error correction term; and strong exogeneity, using both lags and the error correction term. As already mentioned, we estimate a VECM given the previous test results suggesting that cointegration holds between real credit to the private sector and real GDP.

TABLE 2 Results of the Johansen cointegration tests

\begin{tabular}{|c|c|c|c|c|c|c|c|}
\hline & \multicolumn{7}{|c|}{ Null hypothesis: $r=0$; alternative null: $r=1$} \\
\hline & $\begin{array}{l}\text { Max-Eigen } \\
\text { statistic }\left(\lambda_{\max }\right)\end{array}$ & $\begin{array}{l}95 \% \text { critical } \\
\text { value }\end{array}$ & $p$ value & $\begin{array}{l}\text { Trace } \\
\text { statistic }\left(\lambda_{\text {trace }}\right)\end{array}$ & $\begin{array}{l}95 \% \text { critical } \\
\text { value }\end{array}$ & $p$ value & $\boldsymbol{K}$ \\
\hline \multicolumn{8}{|c|}{ Panel A. Countries without Islamic banks } \\
\hline Argentina & 20.301 & 19.387 & $0.036^{* *}$ & 28.015 & 25.872 & $0.027^{* *}$ & 6 \\
\hline Chile & 24.006 & 19.387 & $0.001^{* * *}$ & 29.344 & 25.872 & $0.000^{* * *}$ & 3 \\
\hline Costa Rica & 31.778 & 15.892 & $0.000^{* * *}$ & 37.953 & 20.261 & $0.018^{* *}$ & 3 \\
\hline Ecuador & 51.687 & 15.892 & $0.000^{* * *}$ & 55.901 & 20.261 & $0.000^{* * *}$ & 6 \\
\hline Guatemala & 21.428 & 19.387 & $0.024^{* *}$ & 32.450 & 25.872 & $0.006^{* * *}$ & 6 \\
\hline \multicolumn{8}{|c|}{ Panel B. Countries with Islamic banks } \\
\hline Turkey & 25.734 & 15.892 & $0.001^{* * *}$ & 34.426 & 20.261 & $0.000^{* * *}$ & 5 \\
\hline Iran & 21.888 & 14.264 & $0.003^{* * *}$ & 21.913 & 15.494 & $0.005^{* * *}$ & 6 \\
\hline Singapore & 26.653 & 19.387 & $0.004^{* * *}$ & 29.468 & 25.872 & $0.017^{* *}$ & 3 \\
\hline Jordan & 15.937 & 14.264 & $0.027^{* *}$ & 19.701 & 15.494 & $0.011^{* *}$ & 4 \\
\hline Tunisia & 19.742 & 19.387 & $0.044^{* *}$ & 27.771 & 25.872 & $0.029^{* *}$ & 3 \\
\hline Malaysia & 17.221 & 14.264 & $0.016^{* *}$ & 18.425 & 15.494 & $0.017^{* *}$ & 5 \\
\hline
\end{tabular}

Note. The table reports the Max-Eigen statistics and Johansen trace statistics (Johansen, 1995). $r$ is the number of cointegration vectors. $K$ is the number of lag lengths based on Schwarz information criterion, subject to the removal of serial correlation. Our model includes RCR (real credit to the private sector), RGDP (real GDP), and three exogenous variables ( $E X$ is the real exchange rate, $I N F$ is the inflation rate, and $I$ is the real interest rate).

** Statistical significance at the $5 \%$ level. ${ }^{* * *}$ Statistical significance at the $1 \%$ level. 
TABLE 3 Results of the Westerlund (2007) panel cointegration test

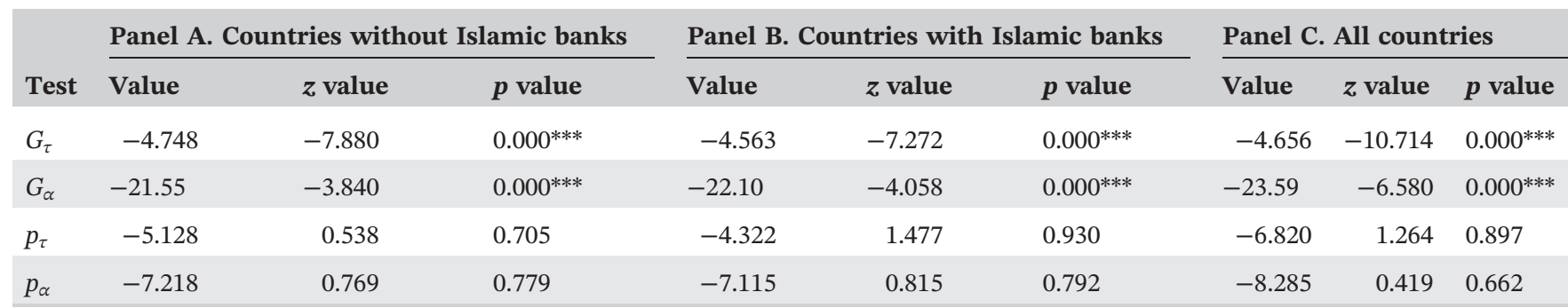

Note. The lag length and the leads are selected according to the Akaike information criterion. $p$ values are one-sided test based on the normal distribution. $\tau$ and $\alpha$ refer to different test statistics. $p_{\tau}$ and $p_{\alpha}$ are pooled test statistics; $G_{\tau}$ and $G_{\alpha}$ are group-mean test statistics. For further information about both pooled and group-mean test statistics, refer to Persyn and Westerlund (2008). Our model includes RCR (real credit to the private sector), RGDP (real GDP), and three exogenous variables ( $E X$ is the real exchange rate, $I N F$ is the inflation rate, and $I$ is the real interest rate).

***Statistical significance at the $1 \%$ level.

TABLE 4 Error correction model (ECM) test with Johansen cointegrating vectors for countries without Islamic banks

\begin{tabular}{|c|c|c|c|c|c|c|c|c|}
\hline \multirow[b]{2}{*}{ Country } & \multirow[b]{2}{*}{$K$} & \multicolumn{2}{|c|}{$\begin{array}{l}\text { SR Granger noncausality test } \\
\left(H_{0}: \text { all } \varphi_{1 i}=0\right)\end{array}$} & \multicolumn{3}{|c|}{$\begin{array}{l}\text { LR weak exogeneity test } \\
\left(H_{0}: \theta_{1}=0\right)\end{array}$} & \multicolumn{2}{|c|}{$\begin{array}{l}\text { SR + LR strong exogeneity test } \\
\left(H_{0}: \text { all } \varphi_{1 i}=\theta_{1}=0\right)\end{array}$} \\
\hline & & $F$ stat $^{\mathrm{a}}$ & $p$ values & $E C T_{t-1}$ & $t$ stat $^{\mathrm{c}}$ & $p$ values & $F$ stat $^{\text {b }}$ & $p$ values \\
\hline Argentina & 6 & 3.107 & $0.011^{* *}$ & 0.056 & 2.737 & $0.008^{* * *}$ & 3.288 & $0.006^{* * *}$ \\
\hline Brazil & 5 & 3.322 & $0.045^{* *}$ & -0.353 & -2.278 & $0.027^{* *}$ & 5.000 & $0.004^{* * *}$ \\
\hline Chile & 3 & 1.0498 & 0.356 & -0.083 & -2.610 & $0.011^{* *}$ & 2.315 & $0.085^{*}$ \\
\hline Costa Rica & 3 & 4.712 & $0.007^{* * *}$ & -0.187 & -2.942 & $0.005^{* * * *}$ & 4.418 & $0.005^{* * *}$ \\
\hline Ecuador & 6 & 2.968 & $0.047^{* *}$ & -0.629 & -2.898 & $0.013^{* *}$ & 4.264 & $0.012^{* *}$ \\
\hline Guatemala & 6 & 2.410 & $0.064^{*}$ & -0.176 & -0.906 & 0.373 & 2.075 & $0.092 *$ \\
\hline Peru & 3 & 0.709 & 0.588 & -0.021 & -1.346 & 0.183 & 4.572 & $0.001^{* * *}$ \\
\hline \multicolumn{9}{|c|}{ Panel B: $H_{0}: \triangle G D P \nrightarrow \triangle R C R$} \\
\hline \multirow[b]{2}{*}{ Country } & \multirow[b]{2}{*}{$\boldsymbol{K}$} & \multicolumn{2}{|c|}{$\begin{array}{l}\text { SR Granger noncausality test } \\
\left(H_{0}: \text { all } \varphi_{2 i}=0\right)\end{array}$} & \multicolumn{3}{|c|}{$\begin{array}{l}\text { LR weak exogeneity test } \\
\left(H_{0}: \theta_{2}=0\right)\end{array}$} & \multicolumn{2}{|c|}{$\begin{array}{l}\text { SR + LR strong exogeneity test } \\
\left(H_{0}: \text { all } \varphi_{2 i}=\theta_{2}=0\right)\end{array}$} \\
\hline & & $F$ stat & $p$ values & $E C T_{t-1}$ & $t$ stat & $p$ values & $F$ stat & $p$ values \\
\hline Argentina & 6 & 1.007 & 0.4308 & -0.047 & -2.432 & $0.018^{* *}$ & 1.326 & 0.257 \\
\hline Brazil & 5 & 1.394 & 0.258 & -0.038 & -3.989 & $0.000^{* * *}$ & 5.884 & $0.000^{* * *}$ \\
\hline Chile & 3 & 1.246 & 0.295 & -0.011 & -1.076 & 0.286 & 0.993 & 0.402 \\
\hline Costa Rica & 3 & 4.564 & $0.008^{* * *}$ & -0.120 & -3.394 & $0.001^{* * *}$ & 4.064 & $0.007^{* * *}$ \\
\hline Ecuador & 7 & 7.927 & $0.001^{* * *}$ & -0.127 & -4.293 & $0.001^{* * *}$ & 7.360 & $0.001^{* * *}$ \\
\hline Peru & 5 & 0.050 & 0.995 & -0.088 & -2.366 & $0.021^{* *}$ & 1.314 & 0.272 \\
\hline Guatemala & 5 & 2.780 & $0.039 * *$ & -0.146 & -2.278 & $0.031^{* *}$ & 2.434 & $0.054^{*}$ \\
\hline
\end{tabular}

Note. $K$ is number of lags in ECM. In Panel A, $F$ stat $^{\mathrm{a}}$ is of the Wald statistics test for the significance of the null hypothesis $H_{0}:$ all $\varphi_{1 i}=0, F$ stat ${ }^{\mathrm{b}}$ is of the Wald statistics test for the significance of the null hypothesis $H_{0}:$ all $\varphi_{1 i}=\theta_{1}=0$, and $t$ stat $^{\mathrm{c}}$ is of the Wald statistics test for the significance of the null hypothesis $H_{0}: \theta_{1}=0$. Panels A and B are estimated using Equations (3) and (4), respectively. SR is short sun and LR is long run.

*Statistical significance at the $10 \%$ level. **Statistical significance at the $5 \%$ level. ***Statistical significance at the $1 \%$ level.

We test for causality within a VECM framework for the countries where cointegration holds according to the Johansen tests. The results are reported in Tables 4 and 5 ( $t$ statistic and $F$ statistics), respectively. Our analysis focuses mainly on the causal relationship between the two variables of interest in this paper, namely, real credit and real GDP. Real credit to the private sector causes real GDP in the short run in Argentina, Brazil, Ecuador, and Costa Rica at the 1\% and 5\% levels and at the $10 \%$ level in Guatemala. Bidirectional short-run 
TABLE 5 Error correction model (ECM) test with Johansen cointegrating vectors for countries with Islamic banks

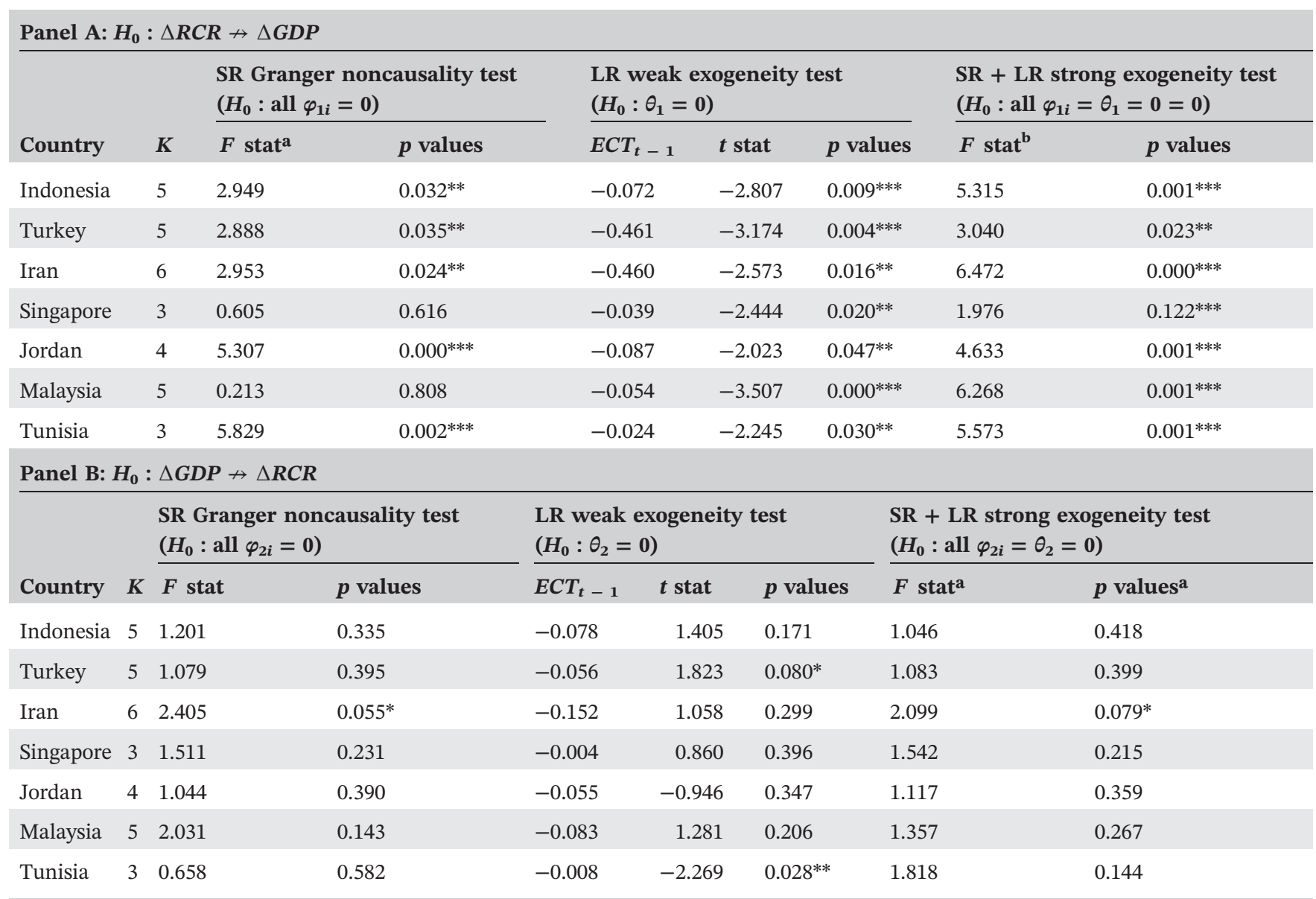

Note. $K$ is number of lags in ECM. In Panel A, $F$ stat ${ }^{\mathrm{a}}$ is of the Wald statistics test for the significance of the null hypothesis $H_{0}:$ all $\varphi_{1 i}=0, F$ stat ${ }^{\mathrm{b}}$ is of the Wald statistics test for the significance of the null hypothesis $H_{0}:$ all $\varphi_{1 i}=\theta_{1}=0$, and $t$ stat ${ }^{\mathrm{a}}$ is of the Wald statistics test for the significance of the null hypothesis $H_{0}: \theta_{1}=0$. Panels A and B are estimated using Equations (3) and (4), respectively. SR is short sun and LR is long run.

*Statistical significance at the $10 \%$ level. ${ }^{*}$ Statistical significance at the $5 \%$ level. ${ }^{* * *}$ Statistical significance at the $1 \%$ level.

Granger causality is found in Costa Rica, Ecuador, and Guatemala.

As for the long-run weak exogeneity tests, the null hypothesis of noncausality from real credit to the private sector to real GDP is not rejected in Peru and Guatemala at any level. The error correction term has a negative sign in all countries except Argentina. On the other hand, long-run causality from real GDP to real credit to the private sector is found in all countries without Islamic banks except for Chile (see Table 4, Panel B). Finally, the strong exogeneity tests suggest bidirectional causality in all countries except Argentina, Chile, and Peru (see Table 4).

There is evidence of short-run unidirectional causality from real credit to the private sector to real GDP in all countries with Islamic banks except for Singapore and Malaysia and short-run bidirectional causality only in Iran at the $10 \%$ level (see Table 5, Panel A). The weak exogeneity tests indicate that both variables are weakly exogenous at the 5\% level in all countries with Islamic. The strong exogeneity tests imply unidirectional causality except for Iran. Long-run causality from real GDP to real credit is found only in two countries, namely, Tunisia at the 5\% level and Turkey at the $10 \%$ level. It is noteworthy that in the long run, real GDP causes real credit to the private sector in the countries without Islamic banks, whereas causality runs in the opposite direction in the countries with Islamic banks. In brief, our results provide strong evidence of long-run causality running from real credit to real GDP and weak evidence of bidirectional short-run causality in countries with Islamic banks. In contrast, for the countries without Islamic banks, there is strong evidence of long-run causality running from real GDP to real credit.

These findings can be explained in terms of the principles of Islamic finance. As previously mentioned, Islamic banks spur economic growth by providing credit for productive investment (Gulzar \& Masih, 2015; Kammer et al., 2015), their financial transactions being linked to real assets (Askari, 2012; Siddiqi, 2006). Moreover, they provide credit to households and firms not 
normally dealing with the financial system for religious reasons. Further, Islamic banks are more likely to provide funds to small and medium-sized enterprises, which results in higher financial inclusion and possibly higher economic growth (Ebrahim et al., 2017; Imam \& Kpodar, 2016). Our findings are in line with those of Kassim (2016) and Imam and Kpodar (2016), who reported that Islamic banks have a measurable impact on economic growth. Although Choudhury (1999) found no evidence that Islamic banking stimulates output growth in a sample of countries including Turkey, his results might simply reflect the lack of Shariah law-complaint financial products (see Johnson, 2013). Further, Goaied and Sassi (2010) found that Islamic banks do not contribute to economic growth in the oil producing countries (which are excluded from our sample) and this might be explained by the problem facing those countries, known as "the crux of the Dutch disease."11 Our findings in countries with Islamic banks support the supply-leading theory according to which financial institutions increase the supply of credit and therefore GDP (Beck et al., 2014; King \& Levine, 1993).

As for the countries without Islamic banks, our findings do not support the idea that credit or financial development has a crucial role in stimulating economic growth (see King \& Levine, 1993; Levine \& Zervos, 1998, among others). This could be because the effects of credit and financial services depend on the allocation of loans to productive investment projects (see Ang \& McKibbin, 2007). A weak effect could reflect an increase in credit in conjunction with a lack of monitoring from banks (see Gavin \& Hausmann, 1996).

TABLE 6 Results of the panel causality tests

\begin{tabular}{|c|c|c|c|c|}
\hline & $\begin{array}{l}\text { SR Granger noncausality test } \\
\left(H_{0}: \text { all } \varphi_{1, i, k}=0\right)\end{array}$ & $\begin{array}{l}\text { LR weak } \\
\left(H_{0}: \theta_{1, i}\right.\end{array}$ & ty test & $\begin{array}{l}\text { SR + LR strong exogeneity } \\
\left(H_{0}: \text { all } \varphi_{1, i, k}=\theta_{1, i}=0\right)\end{array}$ \\
\hline$K$ & $F$ statistic & $t$ statistic & $p$ values & $F$ statistic ${ }^{a}$ \\
\hline
\end{tabular}

Panel A1. Countries without Islamic banks

8.104

$0.000^{* * *}$

1.551

0.122

8.766

$0.000^{* * *}$

Panel A2. Countries with Islamic banks

1.532

0.136

$-2.555$

$0.011^{* *}$

2.386

$0.009^{* * *}$

Panel A2. All countries

$7 \quad 3.83$

$0.009^{* * *}$

$-0.631$

0.527

3.433

$0.004^{* * *}$

Panel B: $H_{0}: \Delta G D P \nrightarrow \Delta C r$

SR Granger noncausality test
K $\quad F$ statistic $\quad p$ values

LR weak exogeneity test

$\left(H_{0}: \theta_{2, i}=0\right)$

$\boldsymbol{t}$ statistic
SR + LR strong exogeneity test

$\left(H_{0}:\right.$ all $\left.\beta_{2, i, k}=\theta_{2, i}=0\right)$

$F$ statistic $p$ values $^{a}$

Panel B1. Countries without Islamic banks
8

7.357

$0.025^{* *}$

$-2.313$

$0.021^{* *}$

18.112

$0.000^{* * *}$

Panel B2. Countries with Islamic banks

$9 \quad 1.193$

Panel B3. All countries

$$
2.627
$$

0.298

$-1.696$

$0.090^{*}$

1.394

0.175

$0.011^{* *}$

$-1.984$

$0.047^{* *}$

3.242

$0.001^{* * *}$

Note. $K$ is number of lags in error correction model. The total panel observations are 499, 402, and 901 for countries without Islamic banks, with Islamic banks, and all countries, respectively. $F$ statistic is of the Wald statistics test for the significance of the null hypothesis $H_{0}:$ all $\varphi_{1, i, k}=0, F$ statistica is of the Wald statistics test for the significance of the null hypothesis $H_{0}:$ all $\varphi_{1, i, k}=\theta_{1 i}=0$, and $t$ statistic is of the Wald statistics test for the significance of the null hypothesis $H_{0}: \theta_{1 i}=0$. Panels A and B are estimated using Equations (5) and (6), respectively. SR is short sun and LR is long run.

$$
\begin{gathered}
\Delta R G D P_{i t}=\alpha_{1 i}+\sum_{K=1}^{m} \beta_{1, i, k} \Delta R G D P_{i, t-k}+\sum_{k=1}^{m} \varphi_{1, i, k} \Delta R C R_{i, t-k}+\sum_{k=1}^{m} \partial_{1 i, k} \Delta E X_{i, t-k}+\sum_{k=1}^{m} \gamma_{1 i} \Delta I N F_{i, t-k}+\sum_{k=1}^{m} \delta_{1, i, k} \Delta I_{i, t-k}+\theta_{1, i, k} E C T_{\mathrm{i}, t-1}+\epsilon_{1, i, t}, \\
\Delta R C R_{i t}=\alpha_{2 i}+\sum_{k=1}^{m} \varphi_{2, i, k} \Delta R C R_{i, t-k}+\sum_{k=1}^{m} \beta_{2, i, k} \Delta R G D P_{i, t-k}++\sum_{k=2}^{m} \partial_{1 i, k} \Delta E X_{i, t-k}+\sum_{k=2}^{m} \gamma_{1 i} \Delta I N F_{i, t-k}+\sum_{k=1}^{m} \delta_{2, i, k} \Delta I_{i, t-k}+\theta_{2 i} E C T_{i, t-1}+\epsilon_{2, i, t} .
\end{gathered}
$$


The panel causality test results are shown in Table 6 . As already mentioned, the lag length is selected according to the Schwarz Bayesian criterion subject to the removal of the serial correlation in the error term. In the countries with Islamic banks, long-run causality from real credit to real GDP is found at the 5\% level while the $F$ statistic fails to reject the null hypothesis of no causality in the short run (see Table 6, Panel A2). By contrast, short-run causality from real credit to GDP is found for countries without Islamic banks (see Table 6, Panel A1). There is evidence of long-run causality from real GDP to real credit in countries without Islamic banks (there is also some weaker evidence, at the $10 \%$ level, in countries with Islamic banks), but no evidence of short-run causality in countries with Islamic banks (see Table 6, Panel B). The diagnostic tests (not reported) suggest data congruence.

Further, to check the stability of our models, we run both the cumulative sum and the cumulative sum of squares with recursive residuals following Pesaran and Pesaran (1997). Both tests show that the values of the coefficients stay within the boundaries of the $5 \%$ significance level, so the null hypothesis of stable coefficients is accepted for both the short-run and long-run parameters in our ECM models (see Brown, Durbin, \& Evans, 1975; Samargandi, Fidrmuc, \& Ghosh, 2014; see Figures B1, B2, B3, B4 for a sample of the results; full results are available on request).

On the whole, the long-run results obtained from the two approaches are rather similar: Both suggest that real GDP causes real credit in the countries without Islamic banks except for Chile, whereas there is causality in the opposite direction in the countries with Islamic banks. Bidirectional short-run causality is found in two countries without Islamic banks (Ecuador Costa Rica and Guatemala, at the 1\% level) and one with Islamic banks (Iran, at the 5\% level). However, there are differences between the two sets of short-run results: The panel tests suggest that short-run causality runs from real credit to real GDP in countries without Islamic banks (and that there is bidirectional causality in one of them,i.e., Iran). Compared with the time series results, the individual countries reveal different causal relationship across the two samples. Time series approaches raise various issues related to the sample size and the power of unit root tests (Christopoulos \& Tsionas, 2004), which we have addressed by performing panel tests as well (Persyn \& Westerlund, 2008).

\section{6 | CONCLUSIONS}

This paper has examined the relationship between real credit to the private sector and real GDP in two sets of emerging countries, with and without Islamic banks, with the aim of shedding light on the effects of Islamic banking on economic growth. Our extensive cointegration and causality analysis provide strong evidence of long-run causality running from real credit to real GDP and weak evidence of short-run causality in both directions in the countries with Islamic banks. In contrast, long-run causality appears to run in the opposite direction, that is, from real GDP to real credit, in the countries without Islamic banks. These differences between the two sets of countries can be plausibly attributed to the distinctive features of Islamic banks, which provide loans to projects that are directly linked to real economic activities and are not allowed to engage in speculative transactions, in this way improving the allocation of resources in the economy and boosting long-run economic growth.

Therefore, one could argue that policymakers aiming to stimulate growth should regulate commercial banks to increase the proportion of credit to productive investment and impose limits on engaging in speculative transactions; this is clearly an important issue, given the current debate on the causes of the global financial crisis, and the mounting evidence that excessive credit growth to finance speculative, unproductive activities was one of its main causes (see Bernanke, 2009; Turner, 2009). In addition, they should favour a bigger market share for Islamic banks in the countries where they are present.

Future research should also consider possible non-linearities in the relationship between credit and growth and examine the robustness of the results by using other measures of credit such as total credit, the credit-to-GDP gap, and credit to nonfinancial sector (see Drehmann et al., 2011; Drehmann \& Tsatsaronis, 2014). ${ }^{12}$

\section{ENDNOTES}

${ }^{1}$ Hadith stands for the actions and quotations of the Prophet Mohammad, which are one of the main sources of Islamic guidance in many aspects of Muslim life including economic activities.

${ }^{2}$ For more details, see Appendix A.

3 "Claims on private sector include gross credit from the financial system to individuals, enterprises, nonfinancial public entities not included under net domestic credit, and financial institutions not included elsewhere" (IMF-IFS line 32d).

${ }^{4}$ Note that the panel approach follows the same estimation process.

${ }^{5}$ For further details on panel unit root tests, see Harris and Sollis (2003), Banerjee (1999), Christopoulos and Tsionas (2004), and Breitung and Pesaran (2008), among others.

${ }^{6}$ These tests are not reported but are available upon request.

${ }^{7}$ The Engle-Granger cointegration test results suggest the existence of a cointegration relationship between credit and GDP only in Ecuador and Iran (these results are available upon request). However, it is well known that the Engle-Granger cointegration tests have low power in the case of a relatively short sample such as ours (see Banerjee, Dolado, Hendry, \& Smith, 1986; Demetriades \& Hussein, 1996; Kremers, Ericsson, \& Dolado, 1992). 
${ }^{8}$ These tests are not reported but are available upon request.

${ }^{9}$ For a more detailed discussion about including a dummy variable when testing for cointegration, see Juselius and MacDonald (2004).

10 The ECT confirms the existence of a long-run relationship between the two variables in our models. Further, the large deviations from the long run seem to be caused by the 1997 Asian crisis and the 2007 recent financial crisis in most countries in our sample (see Figures C1, C2, C3, C4).

11 The Dutch disease is defined as the negative impact on an economy of any factors that increase the inflow of foreign currency, such as oil reserves (see Apergis, El-Montasser, Sekyere, Ajmi, \& Gupta, 2014).

12 Note, however, that the new data set constructed by the BIS (total credit to the nonfinancial sector) is only available for 40 advanced and emerging economies.

\section{ORCID}

\section{Guglielmo Maria Caporale (D) http://orcid.org/0000-0002- 0144-4135}

\section{REFERENCES}

Abduh, M., \& Omar, M. A. (2012). Islamic banking and economic growth: The Indonesian experience. International Journal of Islamic and Middle Eastern Finance and Management, 5(1), 35-47.

Abedifar, P., Hasan, I., \& Tarazi, A. (2016). Finance-growth nexus and dual-banking systems: Relative importance of Islamic banks. Journal of Economic Behavior \& Organization, 132, 198-215.

Ang, J. B. (2008). A survey of recent developments in the literature of finance and growth. Journal of Economic Surveys, 22(3), 536-576.

Ang, J. B., \& McKibbin, W. J. (2007). Financial liberalization, financial sector development and growth: Evidence from Malaysia. Journal of Development Economics, 84(1), 215-233.

Apergis, N., El-Montasser, G., Sekyere, E., Ajmi, A. N., \& Gupta, R. (2014). Dutch disease effect of oil rents on agriculture value added in Middle East and North African (MENA) countries. Energy Economics, 45, 485-490.

Ariff, M. (1988). Islamic banking. Asian-Pacific Economic Literature, 2(2), 48-64.

Askari, H. (2012). Islamic finance, risk-sharing, and international financial stability. Yale Journal of International Affair, 7(1), 1-8.

Banerjee, A. (1999). Panel data unit roots and cointegration: An overview. Oxford Bulletin of Economics and Statistics, 61(S1), 607-629.

Banerjee, A., Dolado, J. J., Galbraith, J. W., \& Hendry, D. F. (1993) Co-integration, error correction, and the econometric analysis of non-stationary data. Oxford: Oxford University Press.

Banerjee, A., Dolado, J. J., Hendry, D. F., \& Smith, G. W. (1986). Exploring equilibrium relationships in econometrics through static models: Some Monte Carlo evidence. Oxford Bulletin of Economics and Statistics, 48(3), 253-277.

Basel Committee on Banking Supervision (2010). Guidance for national authorities operating the countercyclical capital buffer. Basel Committee, Switzerland, December.
Beck, T., Degryse, H., \& Kneer, C. (2014). Is more finance better? Disentangling intermediation and size effects of financial systems. Journal of Financial Stability, 10(0), 50-64.

Berg, N., \& Kim, J. (2014). Prohibition of Riba and Gharar: A signaling and screening explanation? Journal of Economic Behavior \& Organization, 103, S146-S159.

Bernanke, B. S. (2009). The crisis and the policy response, Speech at the Stamp Lecture, London School of Economics, London, 13 January.

Berthelemy, J., \& Varoudakis, A. (1996). Economic growth, convergence clubs, and the role of financial development. Oxford Economic Papers, 48(2), 300-328.

Breitung, J., \& Pesaran, M. H. (2008). Unit roots and cointegration in panels. Berlin Heidelberg: Springer.

Brown, R. L., Durbin, J., \& Evans, J. M. (1975). Techniques for testing the constancy of regression relationships over time. Journal of the Royal Statistical Society, B, 37, 149-163.

Charemza, W. W., \& Deadman, D. F. (1992). New directions in econometric practice: General to specific modelling, cointegration and vector autoregression. Aldershot, UK: Edward Elgar.

Chang, T., \& Caudill, S. B. (2005). Financial development and economic growth: The case of Taiwan. Applied Economics, 37(12), 1329-1335.

Chapra, M. U. (1992). Islam and the economic challenge (Vol. 17) Islamic Economic Series. Leicester, UK: Islamic Foundation.

Cheung, Y., \& Lai, K. S. (1993). Finite-sample sizes of Johansen's likelihood ratio tests for cointegration. Oxford Bulletin of Economics and Statistics, 55(3), 313-328.

Chong, B. S., \& Liu, M. (2009). Islamic banking: Interest-free or interest-based? Pacific-Basin Finance Journal, 17(1), 125-144.

Choudhury, M. (1999). Resource mobilization and development goals for Islamic banks, Proceedings of the Second Harvard University Forum on Islamic Finance: Islamic Finance into the 21st Century, 31-50

Christopoulos, D. K., \& Tsionas, E. G. (2004). Financial development and economic growth: Evidence from panel unit root and cointegration tests. Journal of Development Economics, 73(1), 55-74.

Demetriades, P. O., \& Hussein, K. A. (1996). Does financial development cause economic growth? Time-series evidence from 16 countries. Journal of Development Economics, 51(2), 387-411.

Di Mauro, F., Caristi, P., Couderc, S., Di Maria, A., Ho, L., Kaur Grewal, B., ... Zaheer, S. (2013). Islamic finance in Europe, Occasional Paper Series No. 146. European Central Bank.

Dickey, D. A., \& Fuller, W. A. (1981). Likelihood ratio statistics for autoregressive time series with a unit root. Econometrica, 49, 1057-1072.

Dimitraki, O., \& Menla Ali, F. (2015). The long-run causal relationship between military expenditure and economic growth in china: Revisited. Defence and Peace Economics, 26(3), 311-326.

Drehmann, M. (2013). Total credit as an early warning indicator for systemic banking crises, BIS Quarterly Review, June, 41-45.

Drehmann, M., Borio, C., \& Tsatsaronis, K. (2011). Anchoring countercyclical capital buffers: The role of credit aggregates. International Journal of Central Banking, 7(4), 189-240. 
Drehmann, M., \& Tsatsaronis, K. (2014). The credit-to-GDP gap and countercyclical capital buffers: Questions and answers, BIS Quarterly Review, March, 55-73.

Ebrahim, M. S., Molyneux, P., \& Ongena, S. (2017). Finance and development in Muslim economies. Journal of Financial Services Research, 51(2), 165-167.

El-Gamal, M. A. (2006). Islamic finance: Law, economics, and practice. New York: Cambridge University Press.

Engle, R. F., Hendry, D. F., \& Richard, J. F. (1983). Exogeneity. Econometrica: Journal of the Econometric Society, 277-304.

Engle, R. F., \& Granger, C. W. (1987). Co-integration and error correction: Representation, estimation, and testing. Econometrica, 55, 251-276.

Furqani, H., \& Mulyany, R. (2009). Islamic banking and economic growth: Empirical evidence from Malaysia. Journal of Economic Cooperation and Development, 30(2), 59-74.

Gavin, M., \& Hausmann, R. (1996). The roots of banking crises: The macroeconomic context. In R. Hausmann, \& L. Rojas-Suarez (Eds.), Banking crises in Latin America. Baltimore: Johns Hopkins University Press.

Gheeraert, L. (2014). Does Islamic finance spur banking sector development? Journal of Economic Behavior \& Organization, 103, S4-S20.

Goaied, M., \& Sassi, S. (2010). Financial development and economic growth in the MENA region: What about Islamic banking development, Institut des Hautes Etudes Commerciales, Carthage.

Griliches, Z. (1967). Distributed lags: A survey. Econometrica, 35, 16-49.

Gulzar, R., \& Masih, A. (2015). Islamic banking: 40 years later, still interest-based? Evidence from Malaysia, MPRA Paper, University Library of Munich, Germany. Available at http:// econpapers.repec.org/RePEc:pra:mprapa:65840.

Haron, S., Ahmad, N., \& Planisek, S. L. (1994). Bank patronage factors of Muslim and non-Muslim customers. The International Journal of Bank Marketing, 12(1), 32-40.

Harris, R., \& Sollis, R. (2003). Applied time series modelling and forecasting. Chichester, UK: Wiley.

Hasan, M., \& Dridi, J., (2010). The effects of the global crisis on Islamic and conventional banks: A comparative study. IMF Working Paper 10 (201).

Hsiao, C. (2007). Panel data analysis-Advantages and challenges. TEST, 16(1), 1-22.

Hsiao, C., Mountain, D. C., \& Ho-Illman, K. (1995). Bayesian integration of end-use metering and conditional demand analysis. Journal of Business \& Economic Statistics, 13(3), 315-326.

Hunter, J., \& Menla Ali, F. (2014). Money demand instability and real exchange rate persistence in the monetary model of USDJPY exchange rate. Economic Modelling, 40, 42-51.

Im, K. S., Pesaran, M. H., \& Shin, Y. (2003). Testing for unit roots in heterogeneous panels. Journal of Econometrics, 115(1), 53-74.

Imam, P., \& Kpodar, K. (2016). Islamic banking: Good for growth? Economic Modelling, 59(C), 387-401.
Johansen, S. (1988). Statistical analysis of cointegration vectors. Journal of Economic Dynamics and Control, 12(2), 231-254.

Johansen, S. (1995). Likelihood-based inference in cointegrated vector autoregressive models. New York: Oxford University Press, Oxford.

Johnson, K. (2013). The role of Islamic banking in economic growth, CMC Senior Theses. Paper 642. Available at http:// scholarship.claremont.edu/cmc_theses/642.

Juselius, K. (2007). The cointegrated VAR model: Methodology and applications. Oxford, UK: Oxford University Press.

Juselius, K., \& MacDonald, R. (2004). International parity relationships between the USA and Japan. Japan and the World Economy, 16(1), 17-34.

Kammer, M. A., Norat, M. M., Pinon, M. M., Prasad, A., Towe, M. C. M., \& Zeidane, M. Z. (2015). Islamic finance: Opportunities, challenges, and policy options. IMF Staff Papers, 15(5), 1-38.

Kao, C. (1999). Spurious regression and residual-based tests for cointegration in panel data. Journal of Econometrics, 90(1), $1-44$.

Kassim, S. (2016). Islamic finance and economic growth: The Malaysian experience. Global Finance Journal, 30, 66-76.

Khan, F. (2010). How 'Islamic' is Islamic banking? Journal of Economic Behavior \& Organization, 76(3), 805-820.

King, R. G., \& Levine, R. (1993). Finance, entrepreneurship and growth. Journal of Monetary Economics, 32(3), 513-542.

Kremers, J. J., Ericsson, N. R., \& Dolado, J. J. (1992). The power of cointegration tests. Oxford Bulletin of Economics and Statistics, 54(3), 325-348.

Levine, R., \& Zervos, S. (1998). Stock markets, banks, and economic growth. American Economic Review, 88, 537-558.

Maddala, G. S., \& Wu, S. (1999). A comparative study of unit root tests with panel data and a new simple test. Oxford Bulletin of Economics and Statistics, 61(S1), 631-652.

Majid, S. A., \& Kassim, S. (2010) Islamic finance and economic growth: The Malaysian experience. Paper presented in Kuala Lumpur Islamic Finance Forum, Kuala Lumpur, 2-5 August 2010.

McKinnon, R. I. (1973). Money and capital in economic development. Washington, D. C: The Brookings Institution.

Mills, P. S., \& Presley, J. R. (1999). Islamic finance: Theory and practice. New York: St. Martin's Press.

Mohieldin, M. (2012). Realising the potential of Islamic finance. World Economics, 13(3), 127-142.

Pakes, A., \& Griliches, Z. (1984). Estimating distributed lags in short panels with an application to the specification of depreciation patterns and capital stock constructs. The Review of Economic Studies, 51(2), 243-262.

Pedroni, P. (2004). Panel cointegration: Asymptotic and finite sample properties of pooled time series tests with an application to the PPP hypothesis. Econometric Theory, 20(03), 597-625.

Persyn, D., \& Westerlund, J. (2008). Error-correction-based cointegration tests for panel data. Stata Journal, 2(8), 232. 
Pesaran, M. H., \& Pesaran, B. (1997). Working with Microfit 4.0: Interactive econometric analysis. Oxford: Oxford University Press.

Phillips, P. C., \& Perron, P. (1988). Testing for a unit root in time series regression. Biometrika, 75(2), 335-346.

Robinson, J. (1953). The rate of interest and other essays. London: Macmillan.

Rousseau, P. L., \& Wachtel, P. (2011). What is happening to the impact of financial deepening on economic growth? Economic Inquiry, 49(1), 276-288.

Samargandi, N., Fidrmuc, J., \& Ghosh, S. (2014). Financial development and economic growth in an oil-rich economy: The case of Saudi Arabia. Economic Modelling, 43, 267-278.

Schumpeter, J. (1911). The theory of economic development. Cambridge, MA: Harvard University Press.

Shaw, E. S. (1973). Financial deepening in economic development. New York: Oxford University Press.

Siddiqi, M. N. (1999). Islamic finance and beyond: Premises and promises of Islamic economics, Proceedings of the Third Harvard University Forum on Islamic Finance: Local Challenges, Global Opportunities.
Siddiqi, M. N. (2006). Islamic banking and finance in theory and practice: A survey of state of the art. Islamic Economic Studies, 13(2), 1-48.

Solarin, S. A., Hammoudeh, S., \& Shahbaz, M. (2018). Influence of economic factors on disaggregated islamic banking deposits: Evidence with structural breaks in Malaysia. Journal of International Financial Markets, Institutions \& Money. https://doi.org/ 10.1016/j.intfin.2018.02.007

Turner, A. (2009). A regulatory response to the global banking crisis, Financial Services Authority, London.

Westerlund, J. (2007). Testing for error correction in panel data. Oxford Bulletin of Economics and Statistics, 69(6), 709-748.

Zaher, T. S., \& Kabir Hassan, M. (2001). A comparative literature survey of Islamic finance and banking. Financial Markets, Institutions \& Instruments, 10(4), 155-199.

How to cite this article: Caporale GM, Helmi MH. Islamic banking, credit, and economic growth: Some empirical evidence. Int J Fin Econ. 2018;23:456-477. https://doi.org/10.1002/ijfe.1632 


\section{APPENDIX A}

\section{ISLAMIC FINANCIAL MODELS}

\begin{tabular}{|c|c|}
\hline $\begin{array}{l}\text { Islamic financial } \\
\text { models }\end{array}$ & Explanation \\
\hline $\begin{array}{l}\text { Musharaka } \\
\quad \text { (partnership) }\end{array}$ & $\begin{array}{l}\text { It is built on the idea of equity participation. Under Musharaka contract, each participant pays a percentage of the } \\
\text { capital in the company. The profits or losses generated from the business will be shared between the owners } \\
\text { based on an agreed profits and losses share called PLS (Ariff, 1988). }\end{array}$ \\
\hline $\begin{array}{l}\text { Mudharabah } \\
\text { (profit sharing) }\end{array}$ & $\begin{array}{l}\text { Mudharabah is a contract between two parties: One party supplies the capital of the company, whereas the other } \\
\text { party will be considered as an entrepreneur. Therefore, the Islamic bank becomes a shareholder on the bases that } \\
\text { any profit or loss occurring from the business is shared between the two parties on a per-determined profit } \\
\text { sharing percentage (Haron, Ahmad, \& Planisek, 1994). }\end{array}$ \\
\hline $\begin{array}{l}\text { Murabahah } \\
\text { (cost plus) }\end{array}$ & $\begin{array}{l}\text { It is a financial contract for buying and selling a particular product. A Murabahah contract should specify the price, } \\
\text { the cost of the item, and the profit margin at the time of signing the contract. The role of the bank in a } \\
\text { Murabahah financial instrument is to finance purchasing the good by buying it on the behalf of the customer. } \\
\text { The bank will resell it to the customer after adding a markup to the cost price (Ariff, 1988; Haron et al., 1994). }\end{array}$ \\
\hline
\end{tabular}




\section{APPENDIX B}

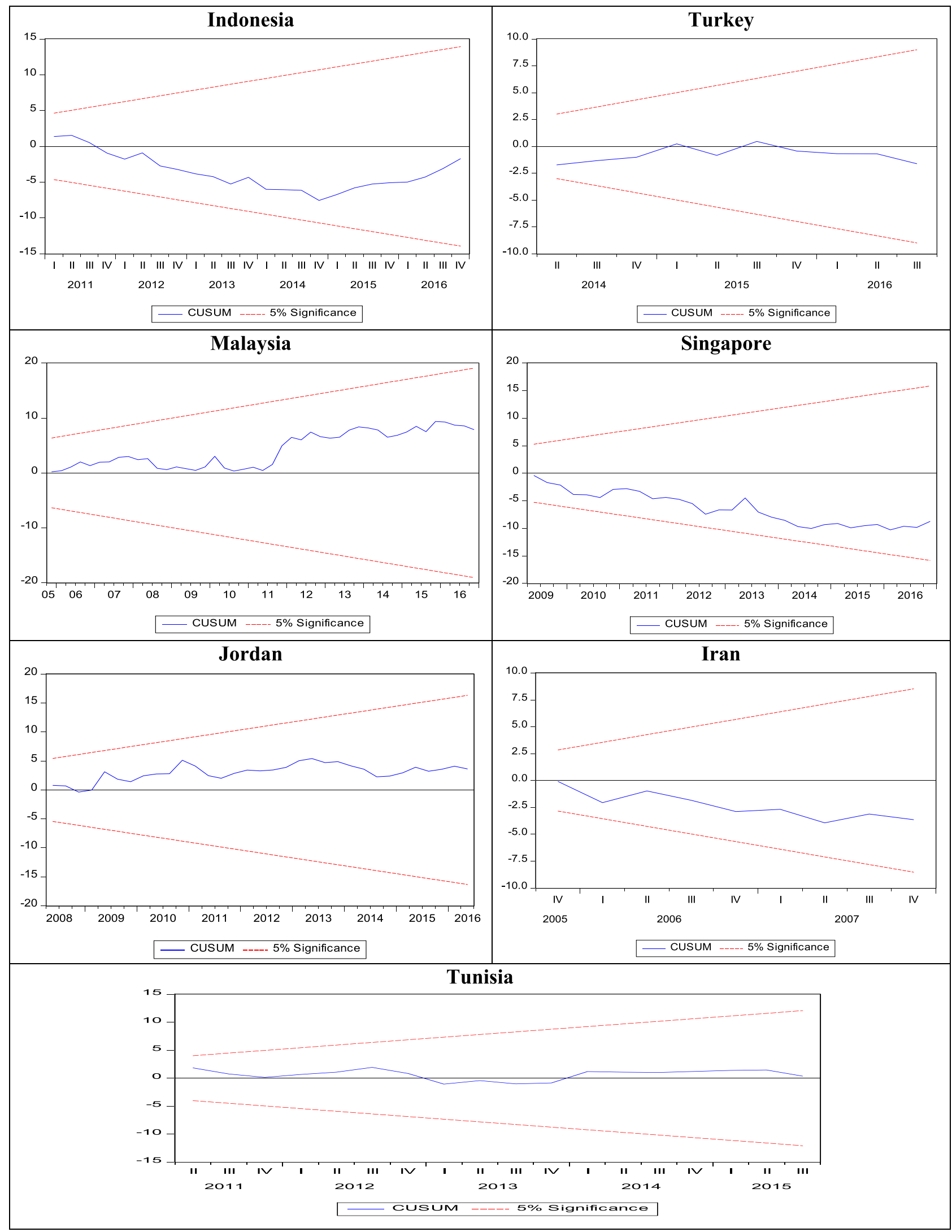

FIGURE B1 Plot of cumulative sum (CUSUM) test for coefficient stability of error correction model—countries with Islamic banks [Colour figure can be viewed at wileyonlinelibrary.com] 


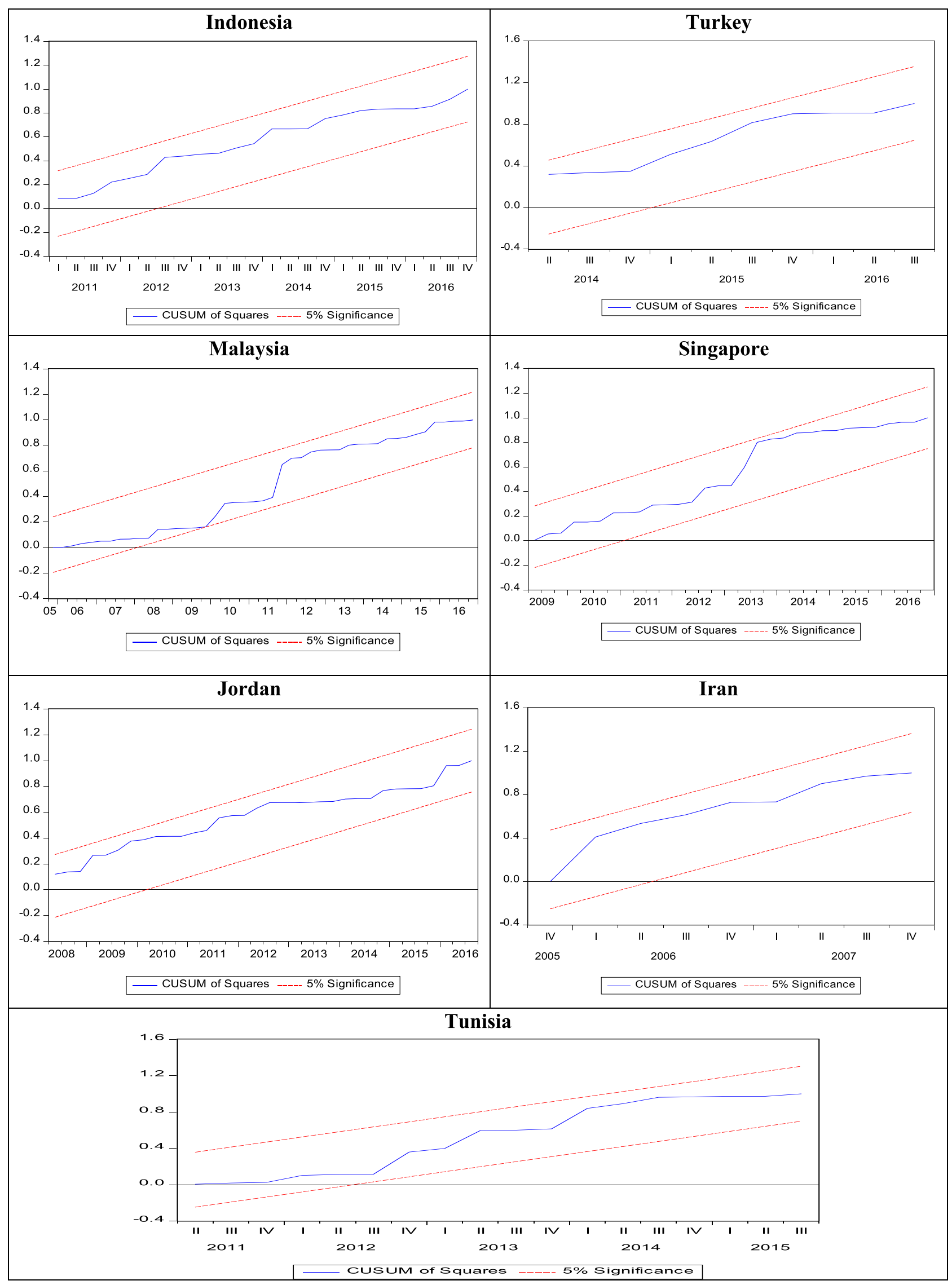

FIGURE B2 Plot of cumulative sum (CUSUM) of squares test for coefficient stability of error correction model—Countries with Islamic banks [Colour figure can be viewed at wileyonlinelibrary.com] 


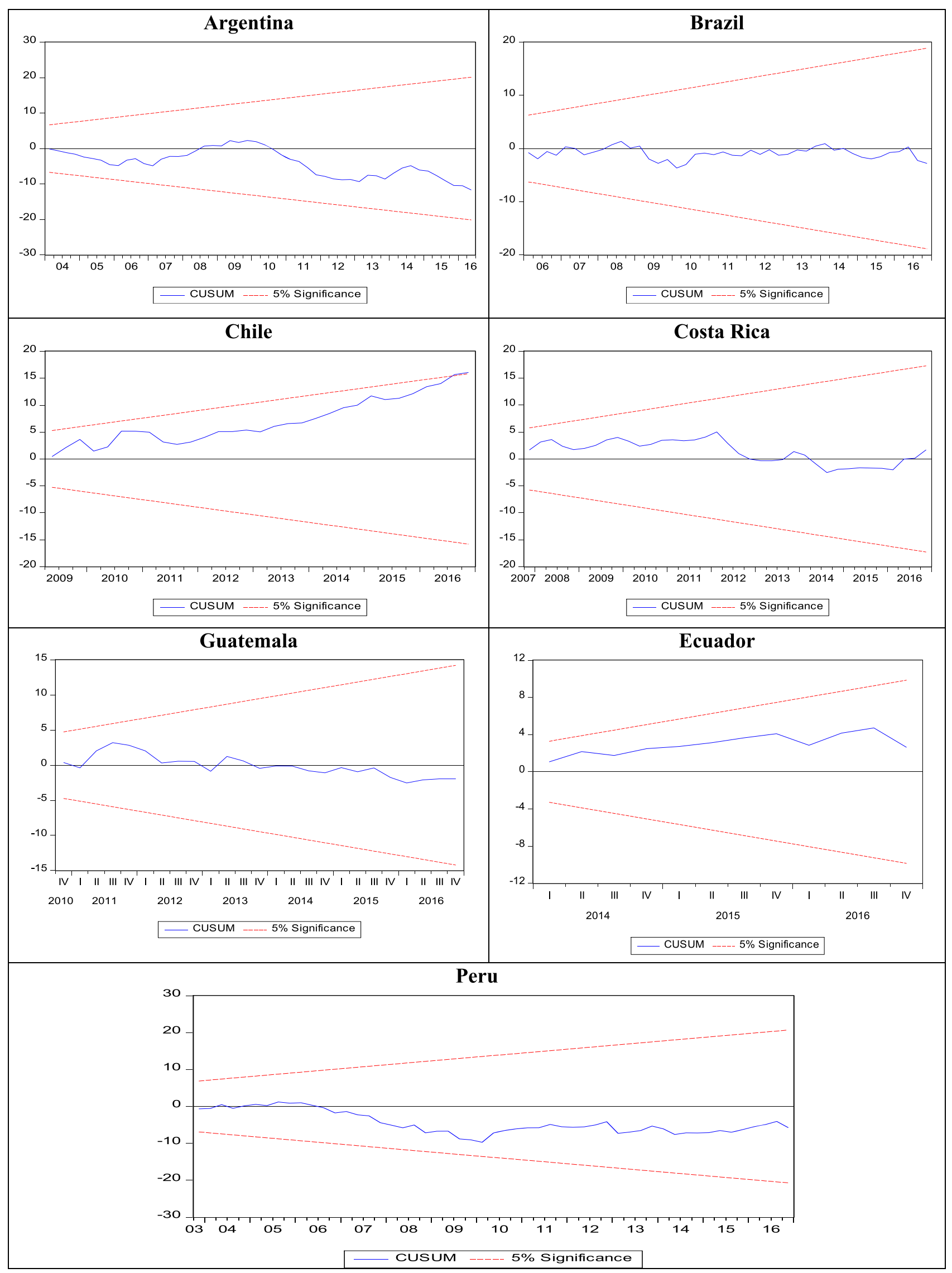

FIGURE B3 Plot of cumulative sum (CUSUM) test for coefficient stability of error correction model—Countries without Islamic banks [Colour figure can be viewed at wileyonlinelibrary.com] 


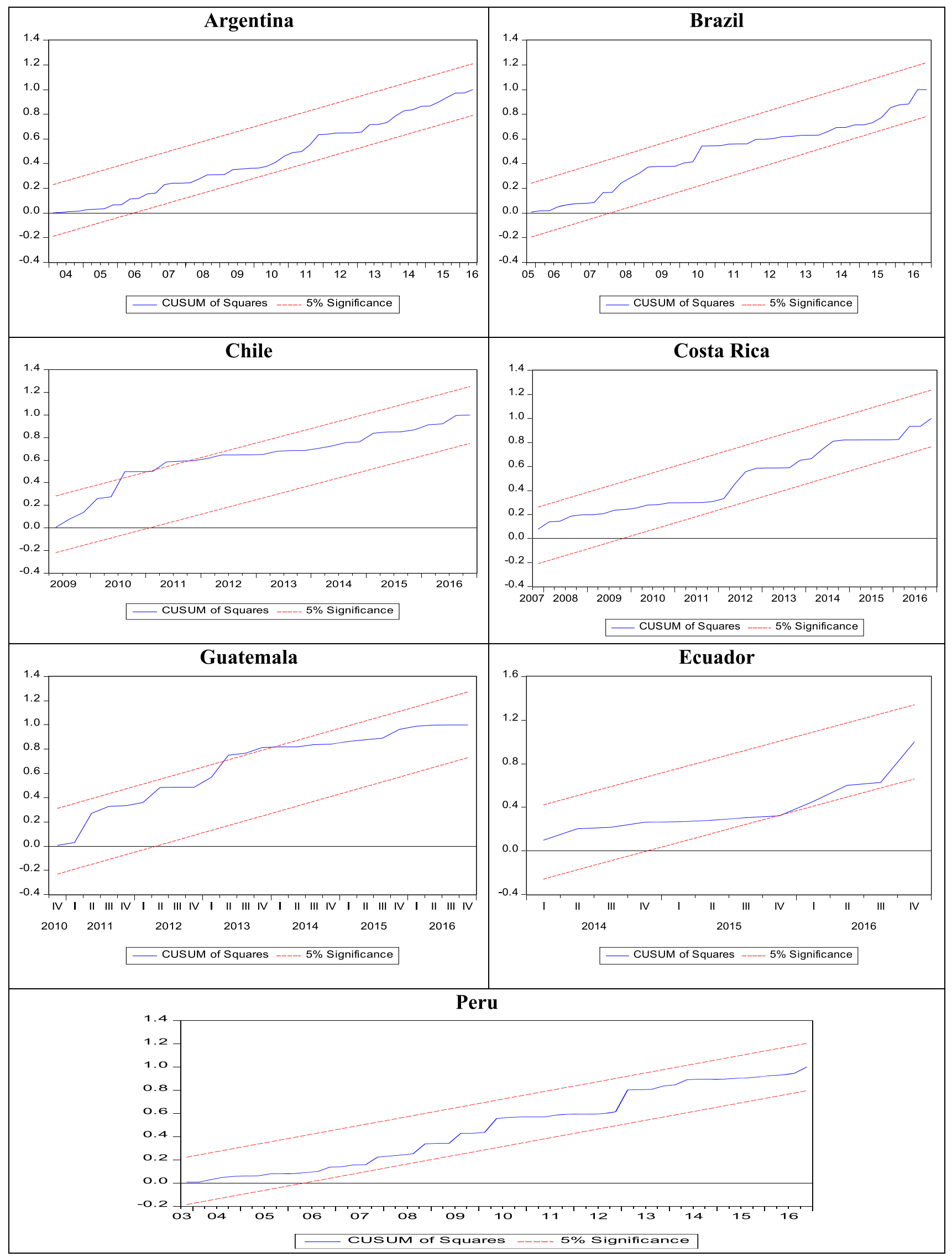

FIGURE B4 Plot of cumulative sum (CUSUM) test for coefficient stability of error correction model—Countries without Islamic banks [Colour figure can be viewed at wileyonlinelibrary.com] 


\section{APPENDIX C}
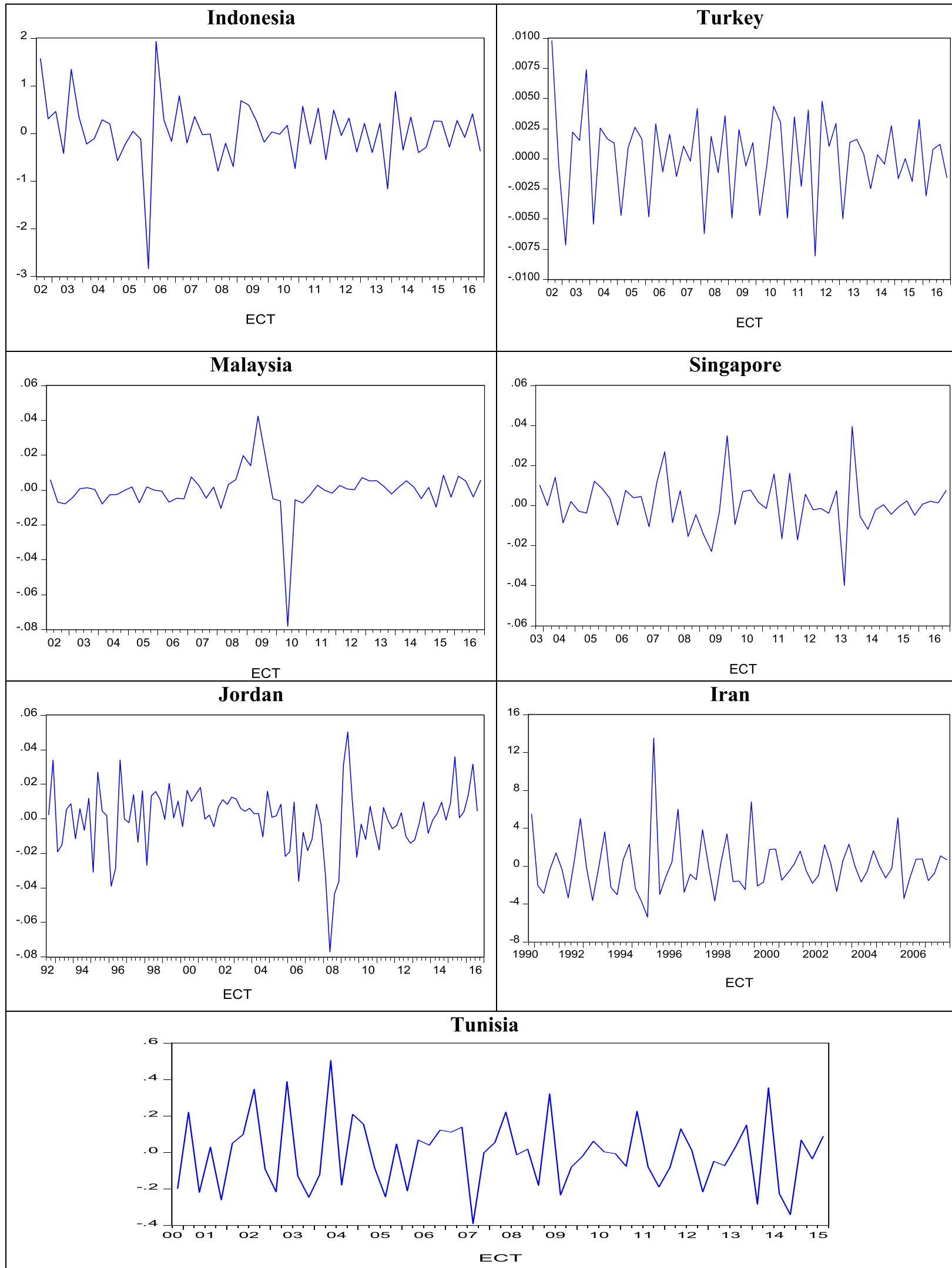

FIGURE C1 Plot of the error correction term (ECT) for countries with Islamic banks (Cr-GDP) [Colour figure can be viewed at wileyonlinelibrary.com] 


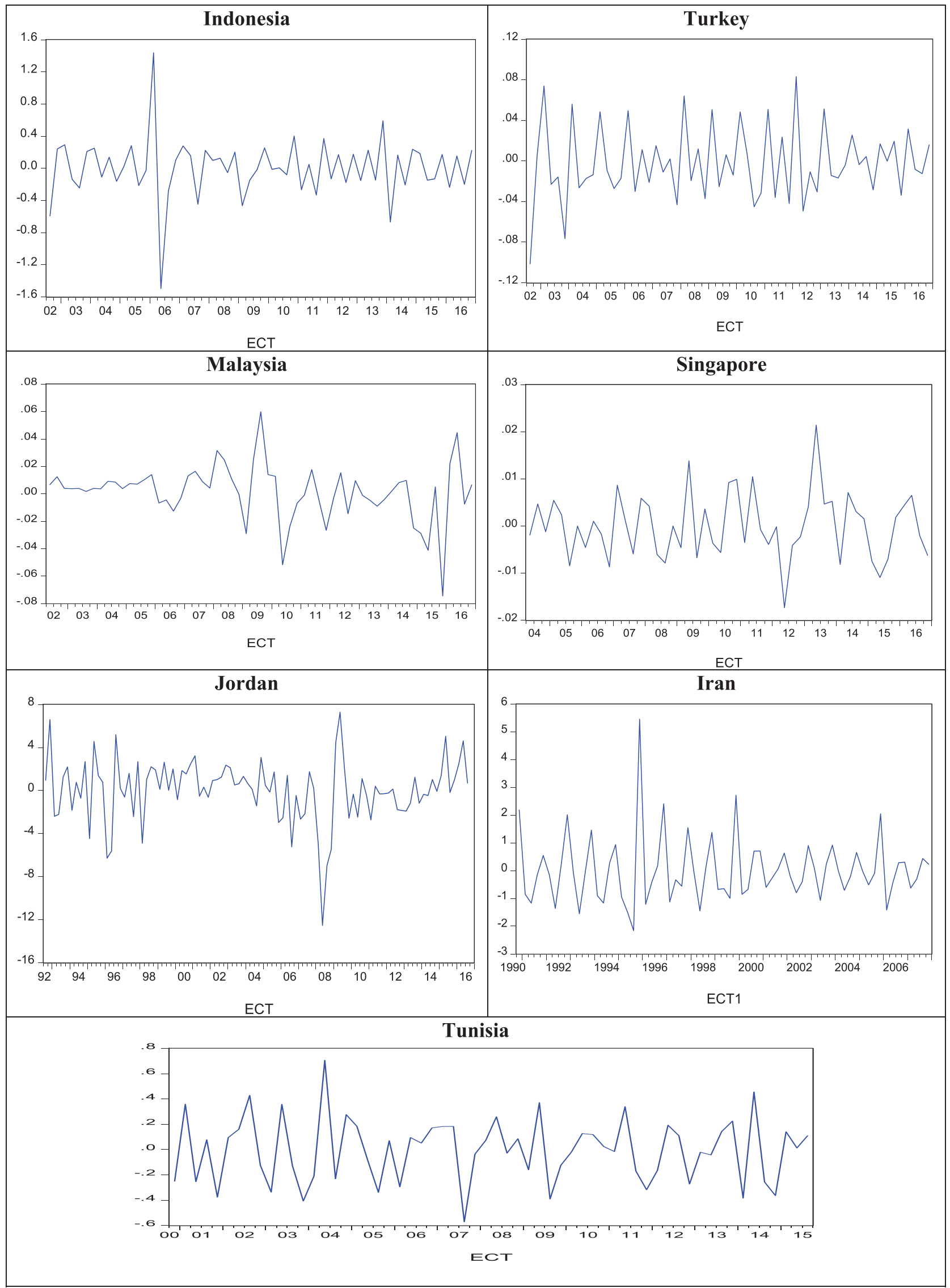

FIGURE C2 Plot of the error correction term (ECT) for countries with Islamic banks (GDP-Cr) [Colour figure can be viewed at wileyonlinelibrary.com] 

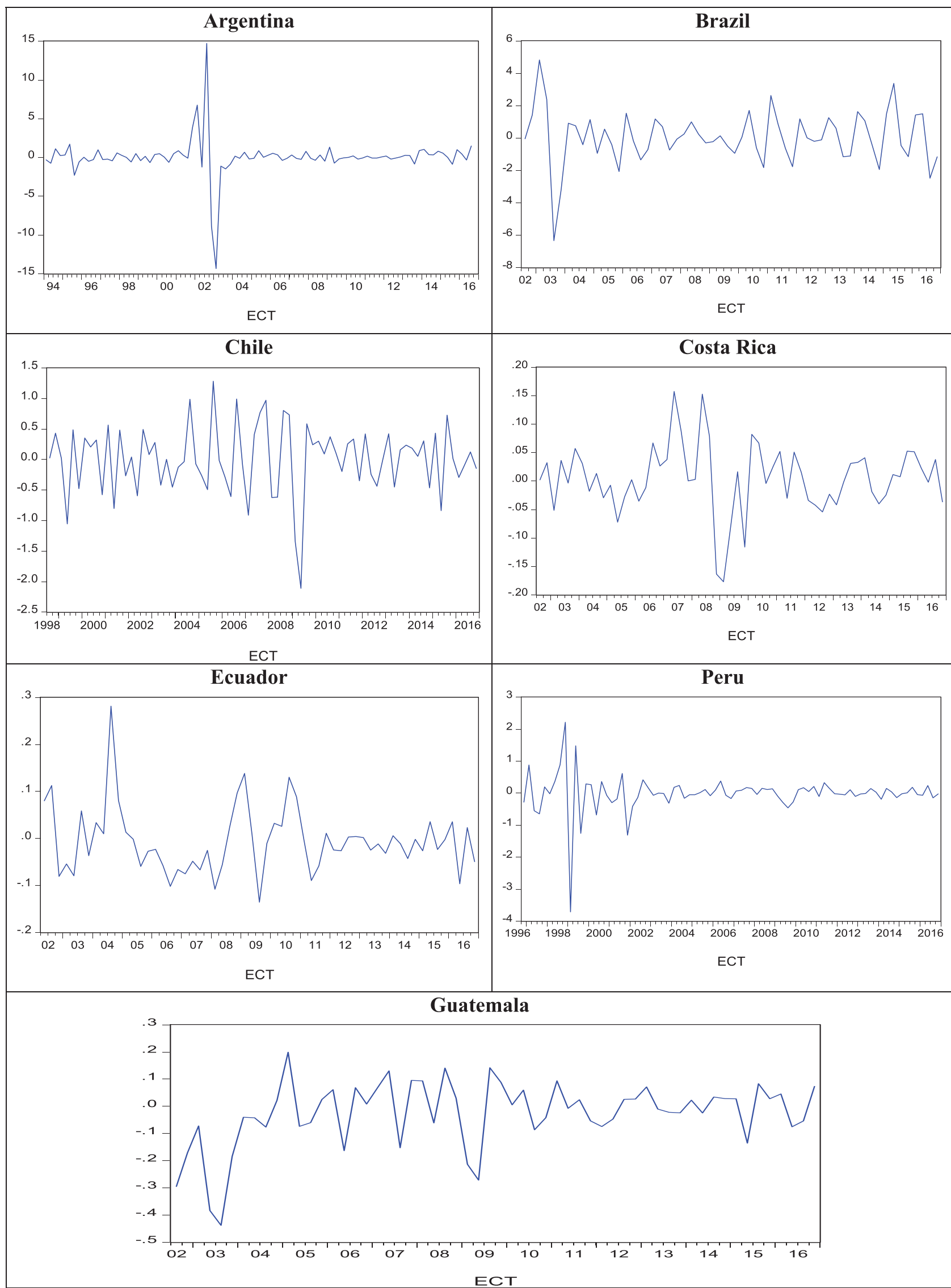

FIGURE C3 Plot of the error correction term (ECT) for countries without Islamic banks (Cr-GDP) [Colour figure can be viewed at wileyonlinelibrary.com] 


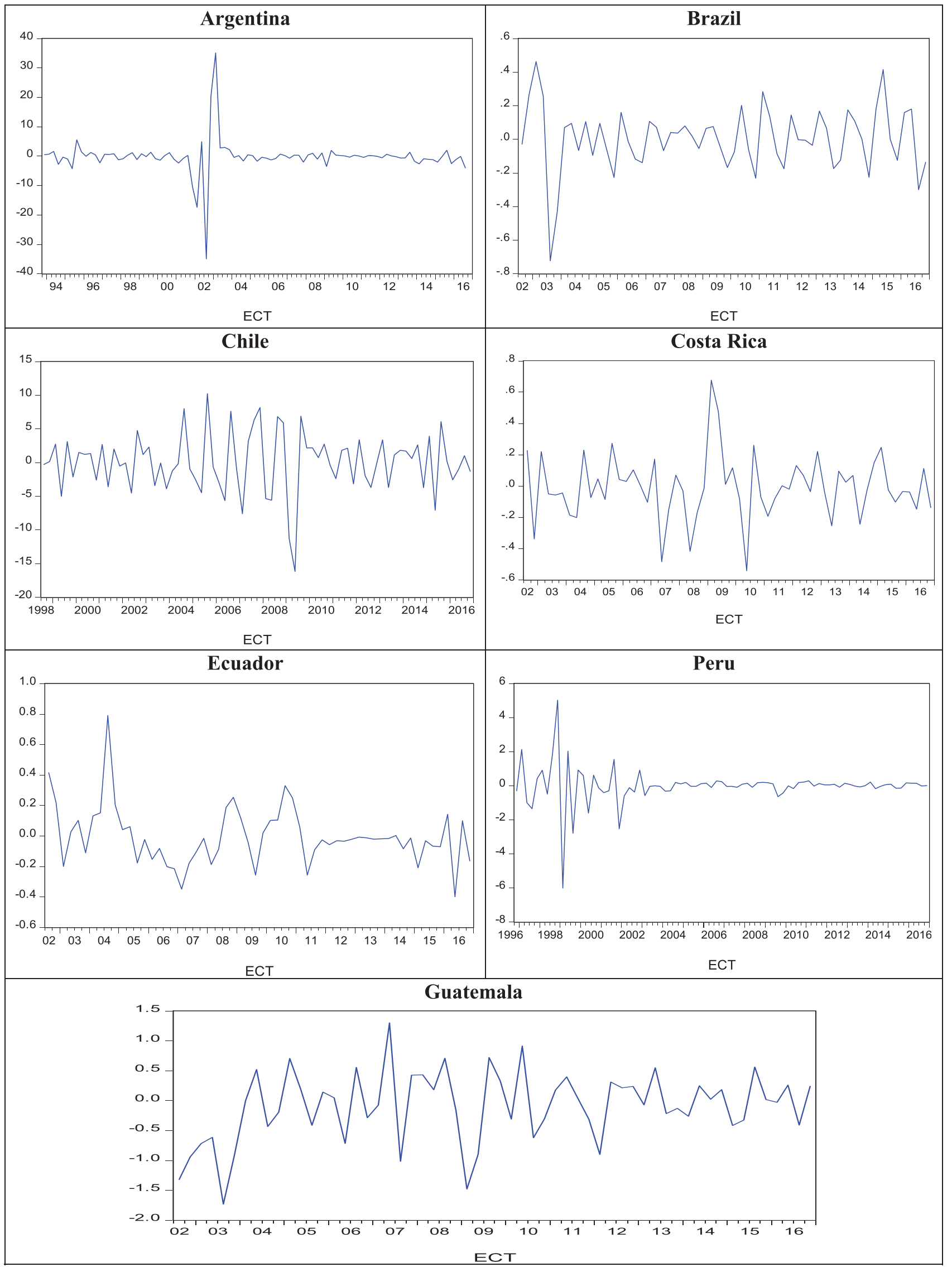

FIGURE C4 Plot of the error correction term (ECT) for countries without Islamic banks (GDP-Cr) [Colour figure can be viewed at wileyonlinelibrary.com] 